\title{
Steel Stiffeners for Enhancement of Slab-Column Connections
}

\author{
Safa S. Kadhim ${ }^{a^{*}}$ and Haider K. Ammash ${ }^{a}$
}

${ }^{a}$ University of Al-Qadisiyah, College of Engineering, Iraq

\section{A R T I C L E I N F O}

\section{Article history:}

Received 09 October 2019

Received in revised form 18 November 2019

Accepted 20 November 2019

\section{Keywords:}

Column Capital

Steel Stiffeners

Finite elements

Flat Slab

Punching Shear Strength.

\begin{abstract}
A B S T R A C T
This paper introduced a strengthening technique for flat plates using steel stiffeners. In this paper, the effectiveness of steel stiffeners with different arrangements and numbers on the punching shear strength. The strengthening steel plates were extended from column to the slab and acted as a column capital of an equivalent concrete column capital. The study was divided into two parts, the first part was the experimental study involves the molding three reinforced concrete flat slab strengthening with different dimensions and numbers of steel stiffeners, with changed the dimensions of steel plates for specimens (SS1 $(100 \times 100 \mathrm{~mm})$, SS2 $(200 \times 200 \mathrm{~mm})$, and SS3 $(300 \times 300 \mathrm{~mm}))$ in addition to reference model without strengthening. The loadcapacity of the strengthened slabs was increased by $(39.84 \%, 57 \%$, and $99.2 \%)$ respectively over that of the control specimen with slabs (SS1, SS2, and SS3). The second part that numerical modeling through the ABAQUS finite element program was introduced. Effect of the steel stiffeners' size and the effect of the column's shape (rectangular and circular) that's deal with steel stiffeners were studied experimentally and numerically. A good agreement was obtained between the experimental and theoretical results.
\end{abstract}

(C) 2019 University of Al-Qadisiyah. All rights reserved.

\section{Introduction}

Slab-column connections are concrete reinforcement slabs with a uniform thickness that transfer loads direct to the support column and are differentiated from other (two-way) systems due to the absence of column capitals, beams, and drop panels. Slab column connections have many advantages such as economical formwork, simple reinforcement layouts that's lead to fast construction. From an architectural point of view, the slab column connections can be used to achieve a smaller overall story height due to the required depth of the low floor structure, and the position of the column and wall is not limited to the position of the beam. However, this type of slab is susceptible to a brittle failure due to punching stresses, highly inducing around columns.

When the loads far below the slab flexural strength of the carrier plate are applied, this causes the punching shear failure to be suddenly Guan and Loo [1]. The failure of a slab-column connection was described off with the term 'punching'. It is correlated to a special failure mechanism in which the column containing part of the slab are pushed together through the slab Alexander and Simmonds [2]. There are many effective methods to enhance the punching shear strength of slab-column connections. Shear reinforcement is one of the methods to increase the punching shear strength. There are different types of shear reinforcement systems such as (steel offcuts, head stirrups, stirrups or shear links, Shear- heads, bent-up bars, and closed stirrups).

A lot of research has been conducted to investigate several techniques for strengthening a flat slab by using several materials to reinforce structural components. Some of the researchers study the influence of using of increasing the thickness of slab on punching shear strength such as Lips et al. [3], the result showed that the increase in slab thickness would develop the punching strength for the specimens (PL4, PL5) with the thickness (320, and $400 \mathrm{~mm}$ ) respectively about $(67 \%$ and $156 \%)$ compared with control specimen PV1 with the thickness $(250 \mathrm{~mm})$. Other researchers like Mabrouk et al. [4] noticed the increasing the punching shear capacity by the addition of steel reinforcement. When the reinforcement of steel bars was added $(5 \varnothing 12 \mathrm{~mm})$ at the tension side to avoid flexural failure to the main reinforcement consisted of steel bars with $(\varnothing 10 \mathrm{~mm})$, the result had

* Corresponding author.

E-mail address: safa.saib89@gmail.com (Safa S. Kadhim) 
shown when the reinforcement ratio was improved about $(20 \%, 45 \%)$ the ultimate punching shear enhanced about $(6 \%$ and $16 \%)$ respectively compared to the control specimen. Qassem et al. [5], studied the influence of using the shear-head reinforcement on the capacity of the punching shear by tested fourteen specimens with embedded shear-head, the specimens with $(1000 \times 1000 \times 70 \mathrm{~mm})$ dimension for the slab and $(150 \times 150 \mathrm{~mm})$ dimension for the column. As a result, discovered that the use of steel plates led to a decrease in ultimate shear stress of about $44 \%, 40 \%, 19 \%$, and $30 \%$ respectively, and the increase in dimensions of the steel plate enhances the ultimate load capacity. Also, the increase in dimensions of the steel plate leads to an increase in the concrete strain in the tension face of the concrete slab and the critical section perimeter. Al-Wetaefi [6], investigated the influence of using HSC with shear reinforcement (bent bars) on the behavior of punching shear strength for the slab-column connection. The shear reinforcement (bent bars) sit at distance $(0.25 \mathrm{~d})$ from the column surface, and the bent bars at the middle was inclined leg at $45^{\circ}$. As a result, showing that bent bars improve the deformation capacity and the ultimate punching shear capacity for the slab-column connections about $20 \%$ and $1.86 \%$ respectively at contrasted with reference specimens. Hassanzadeh and Sundqvist [7], investigated the effect of using doubling and tripling column diameter for column capital. This method of strengthening increased the capacity of punching shear about $60 \%$ and $100 \%$ respectively, related to the control slab. Reinforcement rings worked to prevent the stress of tensile that formed in the column head and to keep the shotcrete at the position through the form of a column head. Besides, using the steel collars attached to the slab and the column worked as a column capital. The strengthening by the steel collars increased the punching capacity of about (70\%) concerning the reference slab. Widianto [8], used the enlarging column part technique to strengthen punching shear, in this technique used the steel collar underneath the slab. The steel collars were formed as the steel tube. As a result of this strengthening, the collar was enhancing the punching shear capacity because of increasing the perimeter critical shear. The punching shear capacity increased about $45 \%$ and the deformation capacities increased about $53 \%$ for flexural reinforcement ratio $(0.5 \%)$ and flexural reinforcement ratio $(1.0 \%)$ the punching shear capacity increased about $42 \%$ and the deformation capacities increased about $15 \%$. Ramos et al. [9], introduces a strengthening technique of two-way slab by using a steel plate and steel bolt. Use eight steel bolts to transfer horizontal forces from the plate to the concrete. The steel plates were formed as two L-shaped plates welded together after being put into place before inserting the steel bolts.

Before strengthening the slabs were loaded up to $50 \%$ from the ultimate capacity of the control slab. The result investigated that plates must surround the column face at the distance least twice from the depth of slab estimated from the face of the column, the least number of bolts must be equal to eight and the minimum plate thickness should be $6 \mathrm{~mm}$. Ammash [10] taken into account in their model compressive strength of concrete, slab depth, the ratio of the flexural reinforcement at the critical section, shape, and dimension of the column, and the position of the critical section. They observed that the flexural reinforcement ratio influence the capacity of the punching shear, the result has shown the increase in the punching shear strength by (17\%) at the increasing the flexural reinforcement ratio from $(0.6 \%)$ to $(2.2 \%)$. Ammash [11] study the effect of using reinforced concrete column capital on the punching shear strength of the flat slab. The study was divided into two lines, the first line was the experimental study involves the molding four reinforced concrete flat slab models with dimensions $(1600 \times 1600 \times 100 \mathrm{~mm})$ with three different dimensions of column capital $(400 \times 400 \mathrm{~mm}, 600 \times 600 \mathrm{~mm}$, and $800 \times 800 \mathrm{~mm})$ in addition to reference model without columns capital (column dimension $200 \times 200 \mathrm{~mm}$ ). The second line that numerical modeling through the ABAQUS finite element program was introduced. The effect of the column's capital size and shape of the column's capital (rectangular and circular) were studied. This paper presented, the experimental and numerical results to study the influence of using steel stiffeners to strengthen reinforced concrete slabs against punching shear failure. And also to investigate the performance of the strengthening technique for increasing the perimeter critical section of punching shear by using steel stiffeners.

\section{Experimental Program}

For slab-column connections were made to describe the experimental part of the investigation. Three connections were strengthened by steel plates and stiffeners, which were installed around columns. The primary test variables were the dimensions and several steel plates and stiffeners. Flat slabs which formed as a square shape, having a dimension of $(1600 \mathrm{~mm})$ and thickness of slab $(100 \mathrm{~mm})$ with the square column have a dimension of $(200 \mathrm{~mm})$. All slabs had the same dimensions and flexural reinforcement equal to the (1.26\%) as well as similar material properties, such as concrete strength (25 MPa) and also designed to fail in punching shear. The flat plates were reinforced with $\Phi 10$-bars, spaced $200 \mathrm{~mm}$ center-to-center. The measured effective depth was $70 \mathrm{~mm}$. The yield strength of the tensile reinforcing steel was $635 \mathrm{MPa}$, and the ultimate tensile strength was $713 \mathrm{MPa}$ was determined experimentally for all specimens. where the steel stiffeners with steel plate work as column capital, the steel plate was used with $(6 \mathrm{~mm})$ thickness and size was taken to represent the distance from the column face to the edge of the plate ( $h$, $2 \mathrm{~h}$, and $3 \mathrm{~h}$ ) for the specimens (SS1, SS2, and SS3) respectively where $\mathrm{h}$ is the thickness of slab $(\mathrm{h}=100 \mathrm{~mm})$. The dimensions of steel plates were 100x100x100, 200x200x200, and 300x300x300 for specimens SS1, SS2, and SS3, respectively. Figure 1 shows the geometry and details of flat slabs under investigation. The investigation focused on comparing the maximum performance of reinforcement slab flat systems with different sizes and number of steel stiffeners.

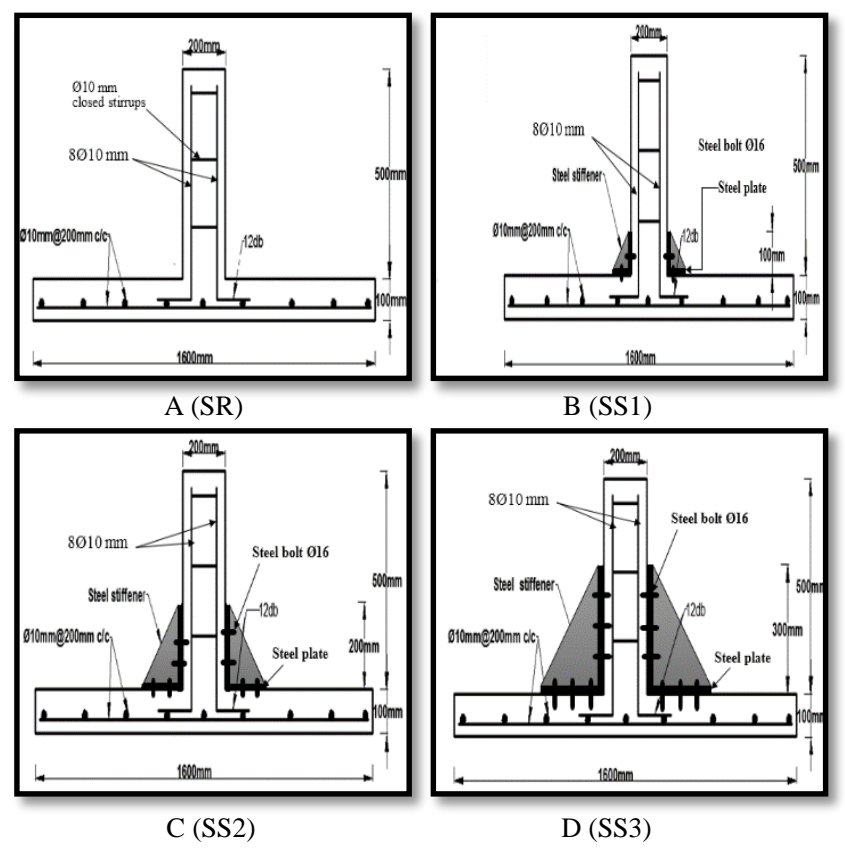

Figure 1. Geometry and Details of Flat Slabs 


\section{Strengthening procedure}

The experimental program of this study includes three specimens that strengthening by using (steel plate and stiffeners) configurations and bolt distribution patterns were provided as shown in Figure 2. The steel stiffeners were used with different numbers at the specimens, where there was one stiffener used in each side of column at the specimen (SS1), two stiffeners used in each side of column at the specimen (SS2), and in the specimen (SS1) was used three stiffeners used in the each side of the column. The steel plates for slabs were four L-shaped plates put into place by inserting the steel bolts and also the steel stiffeners have the triangular shape is put into the middle of the plate and welded together with the steel plate, the steel plate works as a rigid region at the maximum shear position and flexural stress. The rigid region works like the new column capital of comparable concrete of column capital. The reference specimen (unstrengthen) SR, was examined to evaluate the ultimate load and the deflection properties of punching shear strength of the slab. Use a hammer drill to drill slabs and steel plate according to the specific distribution of the bolts. Soon after, the surface of the slab and the holes were carefully cleaned by removing the dust and fine materials with a vacuum cleaner and also after setting the steel plate the welding technique was applied for combining elements to form one part, like as (stiffeners and steel plate) and to connect between it.
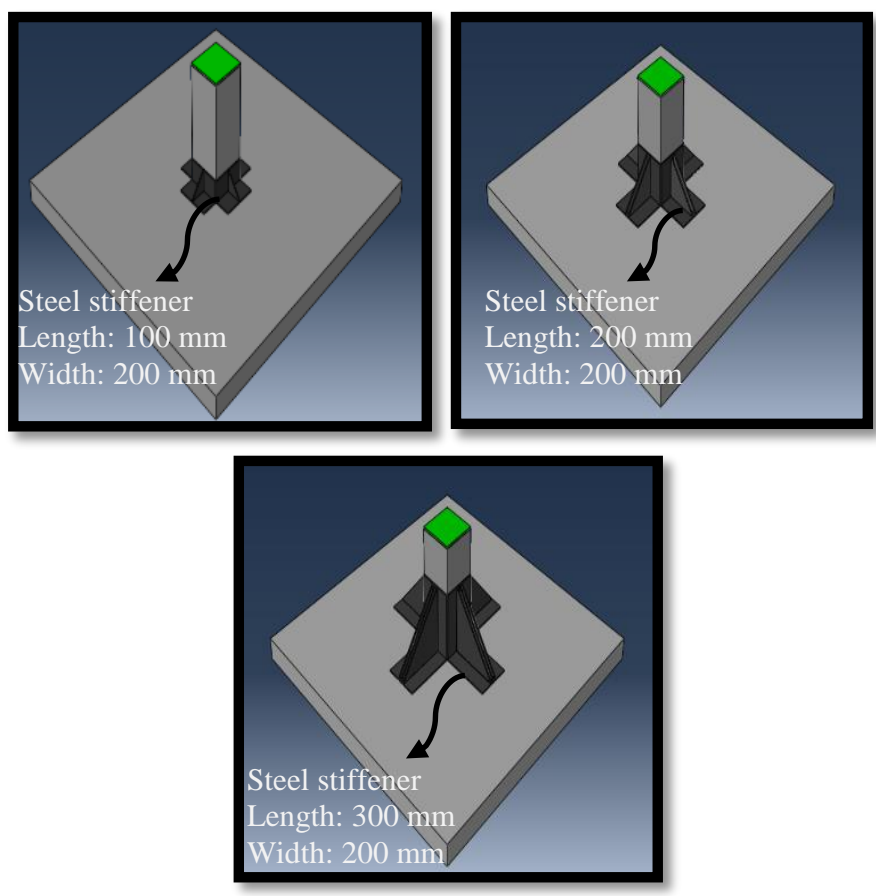

Figure 2. The Slab Column Connection Strengthening with Steel Stiffeners

\section{Experimental Tests}

The experimental program of this study consisted of testing reinforced concrete square slab column connections. One of these slabs employed as a reference model (SR) and the other models employed as a strengthening model where from reinforcements. The specimens were changed by adding the steel plates and stiffeners, while the dimension of steel plate for the specimen SS1 model $100 \times 100 \mathrm{~mm}$ but SS2 model $200 \times 200 \mathrm{~mm}$ and finally for SS3 model $300 \times 300 \mathrm{~mm}$. Under concentrated load, the slab-column connections are tested and simply support for all four edges. The upper face of the column is leveled if there are protrusions to create the plane of the column and avoid the distribution of ununiformed stress. The static load is applied continuously until failure as shown in Figure 3. The load is applied in steps at all $10 \mathrm{kN}$ for the static load. The initial crack load and its position was Observed. At all increasing load, remarks the crack improvement at a concrete of the specimen. The LVDT (Linear Variable Differential Transformer) was used for estimating the deflections of slabs for each step. Apply three vertical LVDTs, a center point for the slab's specimen, one centered in the orthogonal direction of the one-center of the slab specimens, and one in the middle of the diagonal direction of the slab specimen, and applying the load continuously until the specimen's failure.
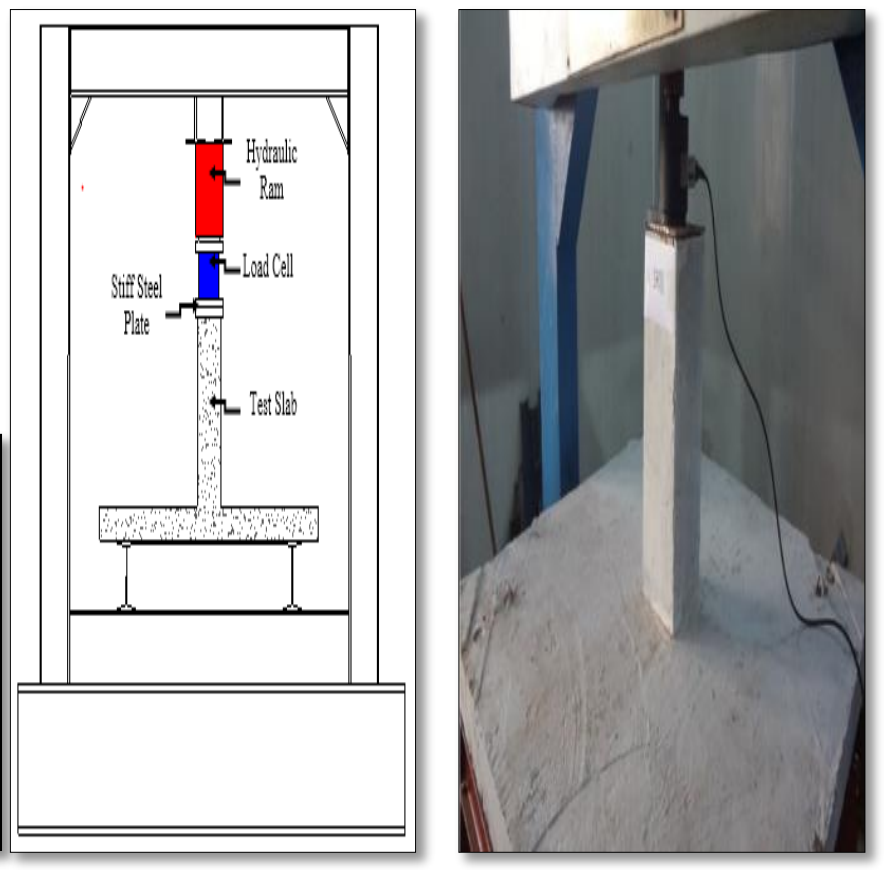

Figure 3. Test setup

\section{Finite Element Modeling}

The ABAQUS / Standard 2016 was used to analyze the nonlinear finite element to compare the analytical results of the finite elements with the experimental results to perform a numerical analysis of the test specimens and also to determine the efficacy and accuracy of the selected analytical finite element model for the suitability of the detected element types, modeling of material, and convergence study of a model representing the shear strengthening normal strength concrete slab column connection subjected to a static load. In this study, the flat slab was analyzing as a threedimensional model. The concrete of its length, width, and depth and also steel plate, and stiffeners are divided into brick elements (Solid elements) (C3D8, 8 nodes linear brick, full integration). The element type (Truss element) (T3D2, linear two-node displacement, Truss element) is used for the reinforcement steel model. The truss elements are embedded in elements that are full contact model between the reinforcement and the concrete as shown in Figure 4. Tie was used to contact between slab surface and steel plates. Convergence studies were made by reducing the element size of the reference model (SR) $(100,75,50,25,20 \mathrm{~mm})$. As can be seen from the convergence study, when the mesh size is reduced from (50 to 20 
$\mathrm{mm}$ ), the change in displacement can be ignored. Further, as the experimental results, the value of the center deflection became more accurate, so the mesh size $(25 \mathrm{~mm})$ was selected for all the tested slabs as shown in figure 4. Polak [12] reported that the specified mesh size should be larger than the maximum size of the aggregate $(20 \mathrm{~mm}$ in the current study).
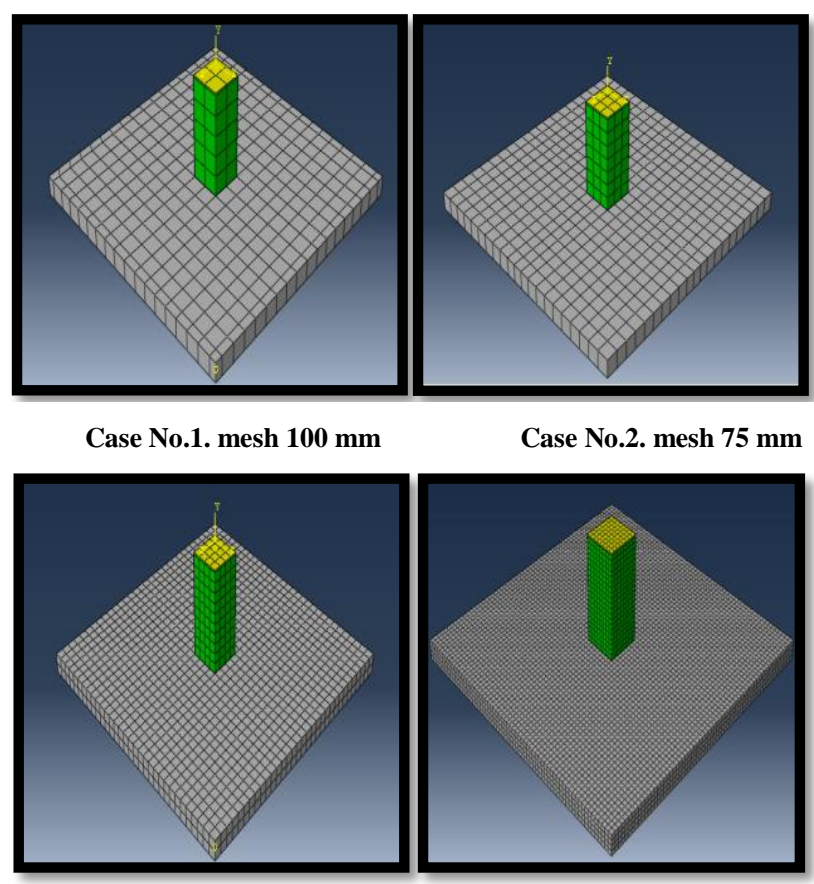

Case No.2. mesh 75 mm

Case No.3. mesh 50 mm

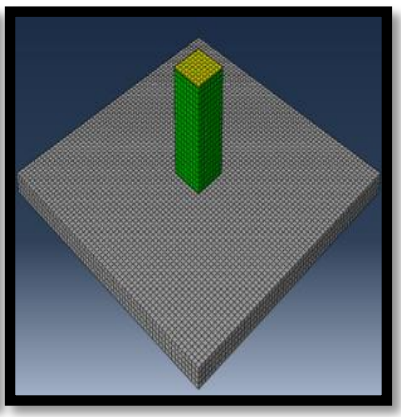

Case No.4. mesh 25 mm

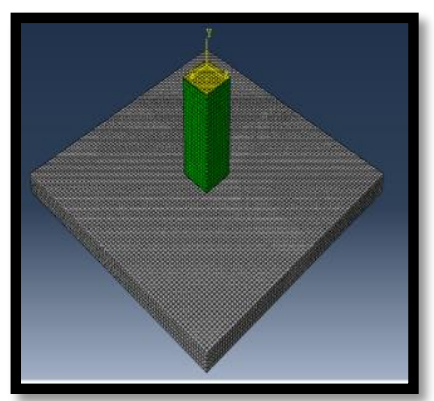

Case No.5. mesh $20 \mathrm{~mm}$

Figure 4. The Convergence Study

\section{Results and Discussion}

\subsection{Failure surfaces}

In the control specimen (SR), the first flexural crack initiated at corners of the column on the tension surface at about (23.39\%) of the ultimate load. For other slabs, the first cracks were observed on the tension surface near the corners and edges of the steel plate at loads of (22.35-18.82) \% of the ultimate load.

The tensile stress in concrete at the stage of loading reached the (modulus of rupture) value and the cracking began in the zone of maximum stress. With more loading, new cracks developed parallel to the diagonal axis and continued towards the slab edge. At the end of loading stages, all the slab-column specimens failed in punching shear. the test results show that the increase in the dimensions of the steel stiffeners develops first cracking load about from $(40,45$, and $48 \mathrm{kN})$ in slab-column specimens such as SS1, slab-column specimen SS2 (with dimensions $200 \times 200 \mathrm{~mm}$ ) and slab-column specimen SS3 (with dimensions $300 \times 300 \mathrm{~mm}$ ). This increasing of the first crack load because the applied load is distributed on the area with relatively large rigidity. Therefore, the stresses in concrete are small and as a result, the stresses of tensile in the concrete reaches the (modulus of rupture) value with large loads. This result because the steel stiffeners work as a column capital, therefore the applied load is distributed on the area with relatively large rigidity as shown in Figure 5.
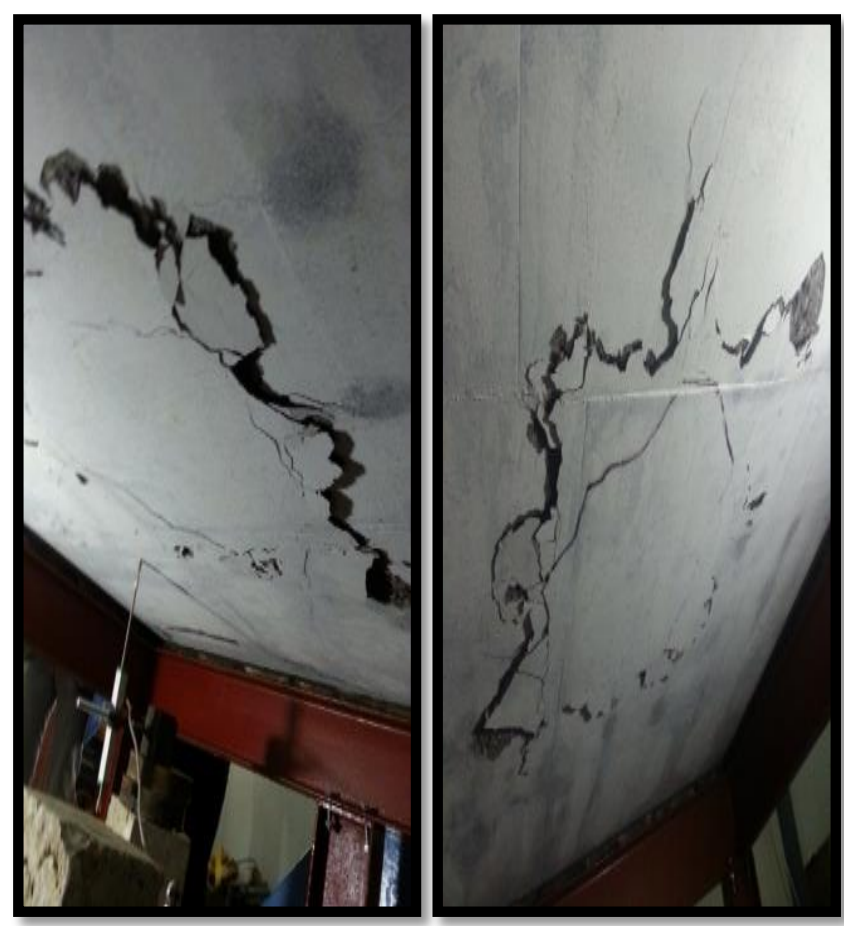

Figure 5. Crack pattern of selected tested slabs

\subsection{2 Ultimate load and deflection}

The deflection curve describes a state of the slab in each $10 \mathrm{kN}$ increment. Deflection curve was measured at the along of the length of the tested specimens (at the center of slabs, $375 \mathrm{~mm}$ from the center of the slab along X-axis, $530 \mathrm{~mm}$ diagonal direction from the center of the slab) by means of three ( LVDT) a Linear Variable Differential Transducers, and reading from this ( LVDT) was recorded to all load increment. When the improvement in the deflections at (the first stages) for the loadings was small with the development at load in an elastic behavior. When the cracks begin growing, the deflections in the slabs develop with a more active rate and continues for developing without an apparent increment in load. Compared to the ultimate load of the reference slab, it is apparent that the strengthening slabs require a higher load than the reference slab to achieve the same deflection that's mean the additional new steel plate with stiffeners was efficient for enhancing the punching strength of slab column connections. Table 1 reviewed the deflection result consistent with the initial crack and the maximum loads for all slab.

When the specimens tested under static load, the results observed that the ultimate punching load for (SS1, SS2, and SS3) higher than the SR (reference specimen) about $(39.84 \%, 57 \%$ and $99.2 \%)$ respectively. When 
the specimens (SS2 and SS3) compared with the specimen SS1 the results showed that the developed in the punching shear strength by about $(12.3 \%$, $42.5 \%$ ) respectively, because increased in the parameter critical section of the steel plates and stiffeners. That's mean the steel stiffeners were efficient in extending the critical shear perimeter, which means that further flexural reinforcement was efficient in the punching cone for increased punching shear capability. More precisely, as the number and the dimension of stiffeners increased, the maximum load was increased. Figure 6 showed the relationship between the reference specimen (unstrengthen) and strengthening technique.

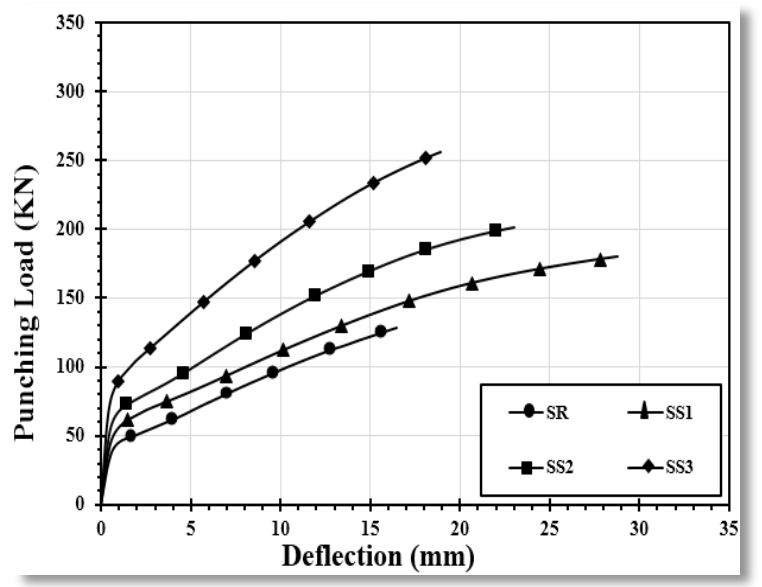

Figure 6. Load-Deflection Curve for Strengthening RC Slab with Steel Stiffeners

Table 1. Ultimate load of tested slabs

\begin{tabular}{lllll}
\hline Specimens & $\begin{array}{l}\text { First } \\
\text { cracking } \\
\text { load (kn) }\end{array}$ & $\begin{array}{l}\text { Ultimate } \\
\text { load } \\
(\mathbf{k n})\end{array}$ & $\begin{array}{l}\text { Ultimate } \\
\text { deflection } \\
\text { ( kn) }\end{array}$ & $\boldsymbol{P} \mathbf{u}_{\text {stif, }} / \boldsymbol{P} \mathbf{u}_{\text {ref. }}$ \\
\hline SR & 30 & 128 & 16 &.--- \\
SS1 & 40 & 179 & 28 & 1.39 \\
SS2 & 45 & 201 & 23 & 1.57 \\
SS3 & 48 & 255 & 18.92 & 1.99 \\
\hline
\end{tabular}

The load-deflection curves from both EXP and FEA results were recorded and plotted for all specimens, as shown in Figure 7 to Figure 10. It can be seen that there is a good agreement between the experimental results and those obtained using the finite element program (ABAQUS).

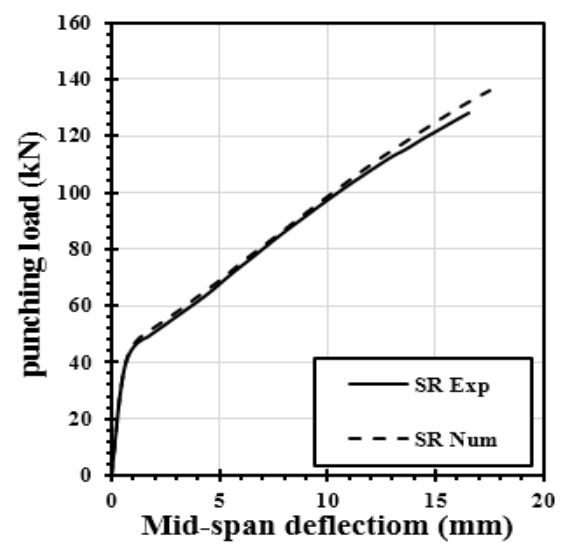

Figure 7. Load-deflection curves for SR specimen

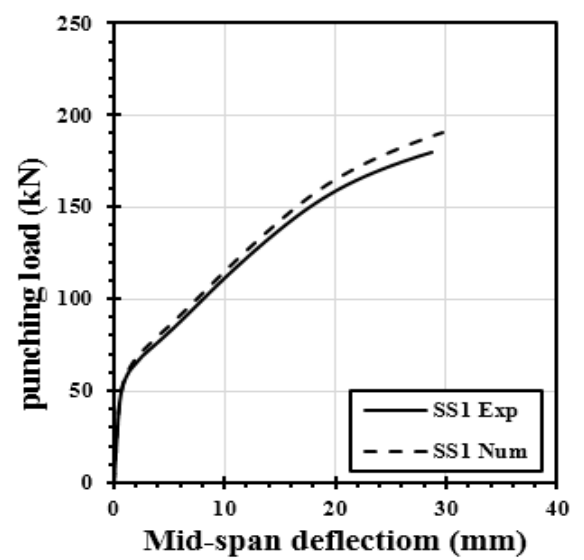

Figure 8. Load-deflection curves for SS1 specimen

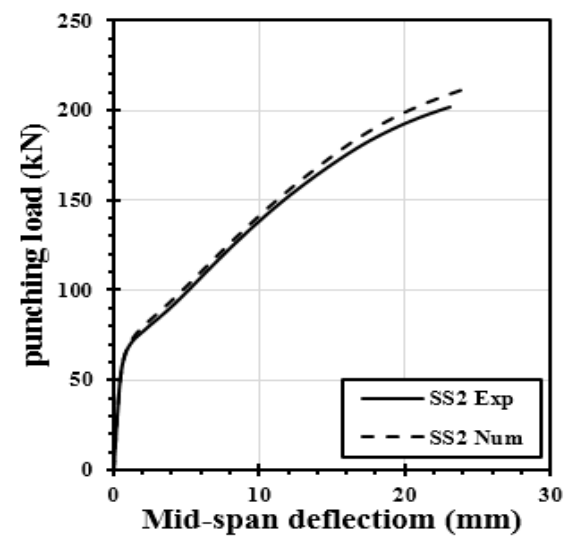

Figure 9. Load-deflection curves for SS2 specimen

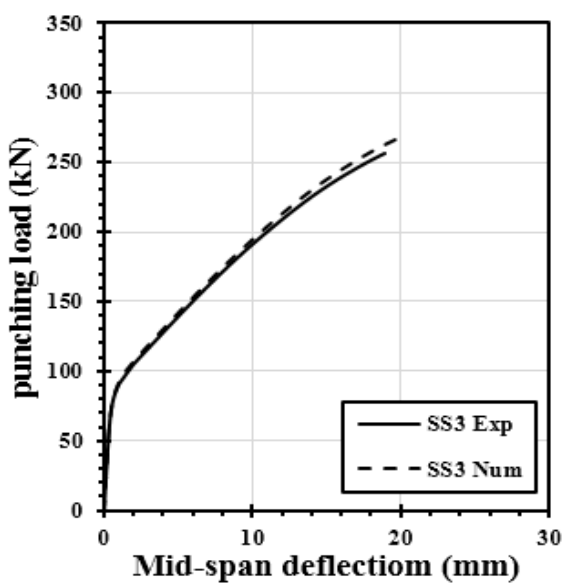

Figure 10. Load-deflection curves for SS3 specimen 


\section{Parametric Study}

This study helps to investigate the different parameters that do not test variables in experimental procedures, and the impact of these parameters on slab behavior, therefor this part can be divided into three main sections such as study the influence of compressive strength of concrete, study the influence of increasing the flexural reinforcement and study the influence of the circular column instead of a square column for the same volume of the square column. Finite Element modeling was used to study these factors. The results of the effect of the compressive strength show that the compressive strength of concrete is one of the most important variables affecting the ultimate load capacity. This is because the contribution of concrete in the compression zone after the formation of the inclined crack depends largely on the strength of the concrete. The comparison between the control specimen and the analytical result showed that the increasing the compressive strength from $(50,75,90 \mathrm{MPa})$ would increase the ultimate load about $(18.23,28.94$, and 36.4$) \%$ respectively and decrease the central deflection about $(-12.6,-7.99$, and -0.78$) \%$ respectively as presented in Table 2 and the Figure 11. Also the results of the effect for increasing the flexural reinforcement on punching shear strength show that the flexural reinforcement of concrete is one of the most important variables affecting the ultimate load capacity. The comparison between the control specimen in this study and the analytical result showed that the increasing the flexural reinforcement $(35 \%, 78 \%$, and $100 \%)$ respectively would increase the ultimate load about $(10.16,23.1$, and 31.12$) \%$ respectively and decrease the central deflection about $(-18.48,-19.22$, and -17.99$)$ as shown in Table 3 and Figure 12.

The comparison between the specimens of this study (the specimen that strengthening with steel stiffeners) and the analytical result showed that the instead of the square column with a circular column with the same volume of concrete in the specimens (SS1-1, SS2-2, and SS3-3) respectively would increase the ultimate load and the central deflection about $(7.72,5.53$, and $6.55) \%$ respectively and $(5.9,7.24$, and 12.69$) \%$ respectively. Figure 13 to Figure 15 and Figure 16 has shown the comparison of the loaddeflection curve between the three specimens and the control specimens (SS1, SS2, and SS3), the load-deflection curve showed a stiff behavior at a circular column compared with the control specimens. That's mean the shape of the column is one of the variables affecting the ultimate load apacity

Table 2. Comparison the Effect of Different values of $\left(\boldsymbol{f}_{c}^{\prime}\right)$ on Ultimate Load

\begin{tabular}{|c|c|c|c|c|c|}
\hline 苞 & $\begin{array}{l}\text { Compressive } \\
\text { Strength } \\
\text { (MPa) }\end{array}$ & $\begin{array}{c}\text { Ultimate } \\
\text { load } \\
(\mathbf{P u}) \\
\text { kN) }\end{array}$ & 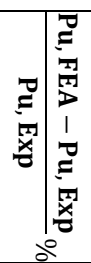 & $\begin{array}{c}\text { Maximum } \\
\text { deflection } \\
(\Delta \mathbf{u}) \\
\text { mm }\end{array}$ & 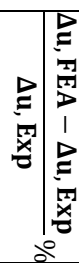 \\
\hline SS3 & 25 & 269.3 & --- & 20.4 & --- \\
\hline SS3-1 & 50 & 318.4 & 18.23 & 17.83 & -12.6 \\
\hline SS3-2 & 75 & 347.24 & 28.94 & 18.77 & -7.99 \\
\hline SS3-3 & 90 & 367.316 & 36.4 & 20.24 & -0.78 \\
\hline
\end{tabular}

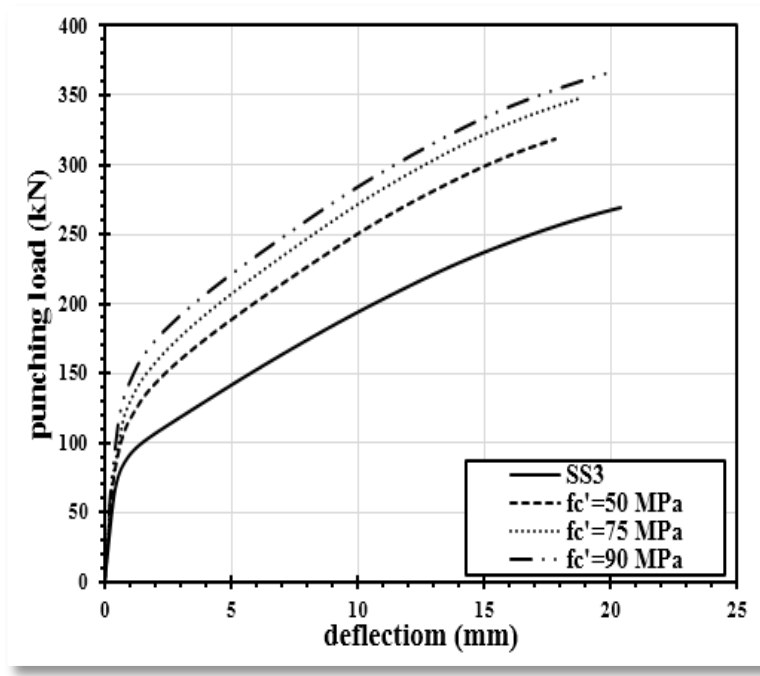

Figure 11. Effect of Concrete Compressive Strength on the Behavior of Slabs

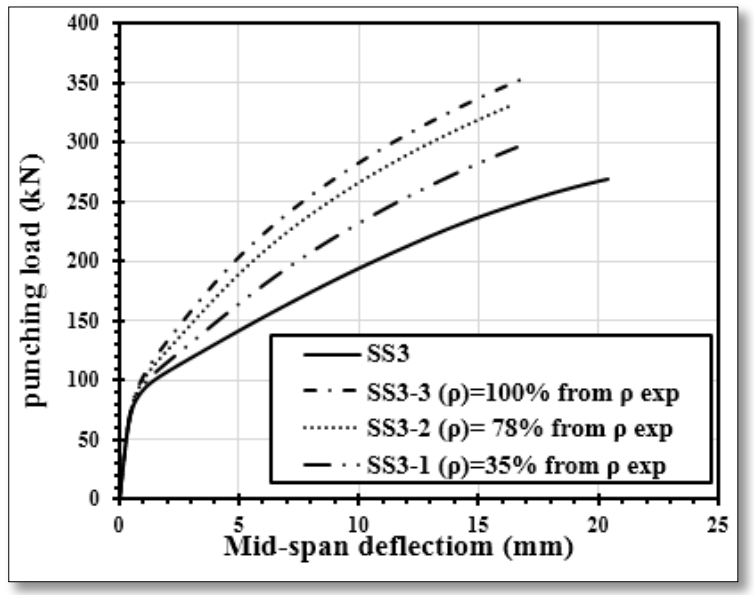

Figure 12. Effect of the Flexural Reinforcement on the Behavior of Slabs

Table 3. Comparison the Effect of Increasing the Flexural Reinforcement on the Behavior of Slabs

\begin{tabular}{|c|c|c|c|c|c|c|}
\hline 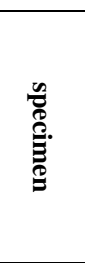 & $\begin{array}{c}\text { The } \\
\text { increasing } \\
\text { flexural } \\
\text { reinforceme } \\
\text { nt ratio }\end{array}$ & $\begin{array}{c}\text { Ultimate } \\
\text { load } \\
(\mathbf{P u}) \\
\text { kN) }\end{array}$ & 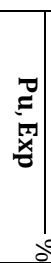 & 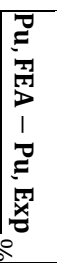 & $\begin{array}{c}\text { Maximum } \\
\text { deflection } \\
(\Delta u) \\
\text { mm }\end{array}$ & 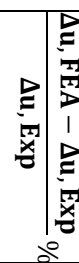 \\
\hline SS3 & --- & 269.3 & --- & & 20.4 & --- \\
\hline SS3-1 & $35 \%$ & 296.66 & 10. & & 16.63 & -18.48 \\
\hline SS3-2 & $78 \%$ & 331.51 & 23. & & 16.48 & -19.22 \\
\hline SS3-3 & $100 \%$ & 353.11 & 31. & & 16.73 & -17.99 \\
\hline
\end{tabular}




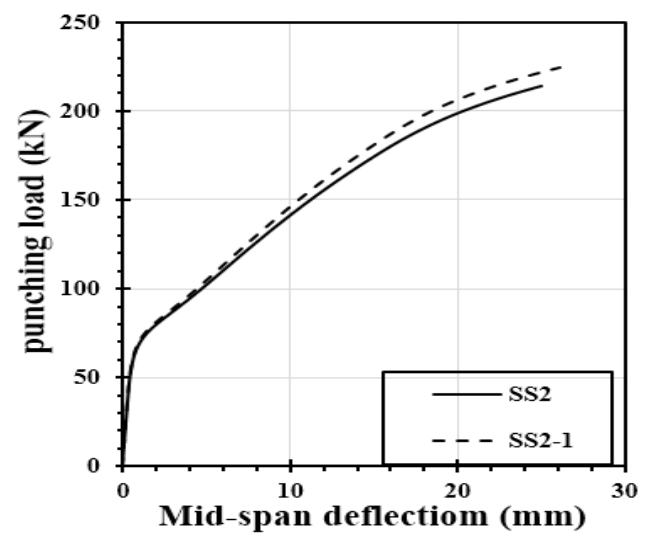

Figure 13. Load-deflection curves for Effect of Circular Column on the Behavior of Slabs for specimen SS1-1 specimen

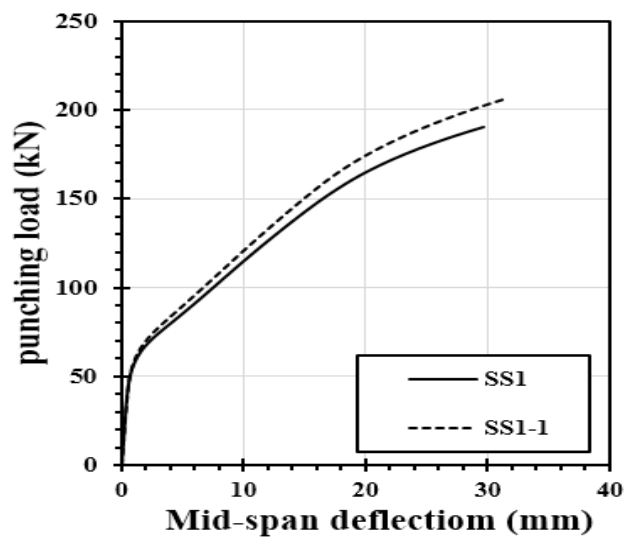

Figure 14. Load-deflection curves for Effect of Circular Column on the Behavior of Slabs for specimen SS2-1 specimen

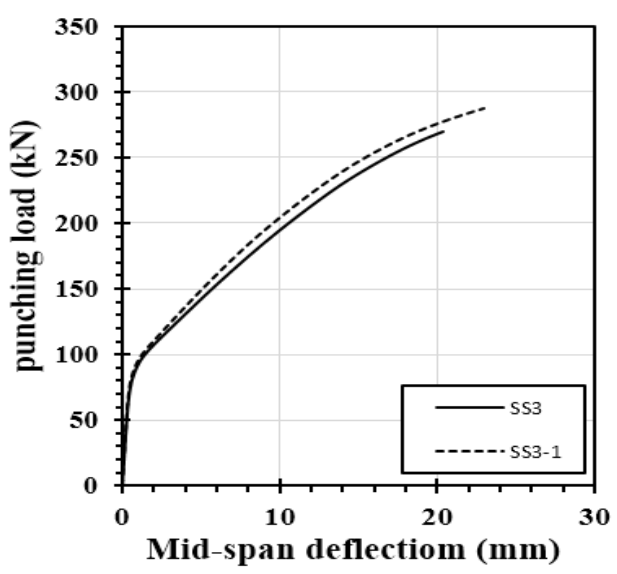

Figure 15. Load-deflection curves for Effect of Circular Column on the Behavior of Slabs for specimen SS3-1 specimen
Table 4. Comparison the Effect of Circular Column on the Behavior of Slabs with the Square Column

\begin{tabular}{ccccc}
\hline Specimen & $\begin{array}{c}\text { The dimension of } \\
\text { Steel Plates } \\
\mathbf{m m}\end{array}$ & $\begin{array}{c}\text { The height of } \\
\text { Steel Plates } \\
\mathbf{m m}\end{array}$ & 100 & 1.077 \\
\hline $\begin{array}{c}\text { SS1 } \\
\text { SS1-1 }\end{array}$ & $100 \times 100$ & 200 & 1.055 & 1.072 \\
$\begin{array}{c}\text { SS2 } \\
\text { SS2-1 }\end{array}$ & $200 \times 200$ & 300 & 1.65 & 1.13 \\
$\begin{array}{c}\text { SS3 } \\
\text { SS3-1 }\end{array}$ & $300 \times 300$ & & & \\
\hline
\end{tabular}
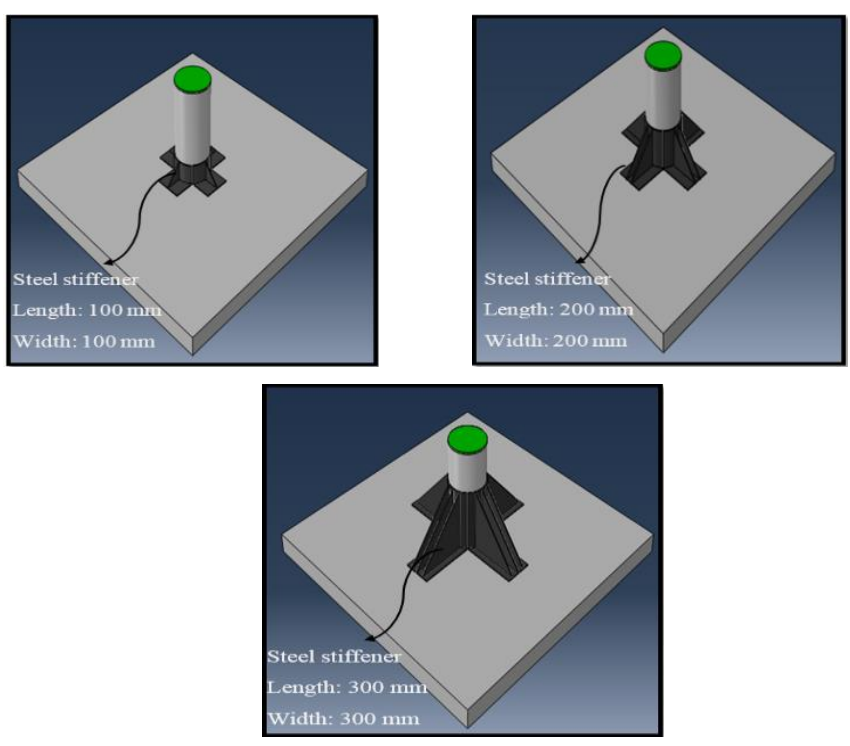

Figure 16. Effect of Circular Column on the Behavior of Slabs

\section{Conclusions}

- The failure perimeter for the slab with (steel stiffeners) increased significantly with increasing the size and number of (steel stiffeners). This means that the size (steel stiffeners) represents the important parameters determining the crushed area (failure perimeter) around the column.

- For the slab strengthening with steel stiffeners (SS1, SS2, and SS3) punching shear capacity will increase to $(39.84 \%, 57 \%$, and $99.2 \%)$ respectively.

- The general behavior observed for load-displacement curves, mode of failure, and crack propagation of slab strengthening with (steel stiffeners) stiffer than slab column connection without strengthen.

- The capacity of the punching shear strength will develop by enhancing the concrete's compressive strength from (50 to 90) MPa about (18.23, 28.94 , and 36.4$) \%$ respectively concerning the specimen with $(25$ $\mathrm{MPa}$ ) compressive strength.

- The increase of the flexural reinforcement with the ratio of $(35 \%, 78 \%$, and $100 \%$ ) respectively with respect to control specimen led to increasing the ultimate load about $(10.16,23.1$, and 31.12) \% respectively.

- The capacity of punching shear showed that using circular columns instead of the square column would increase the ultimate load about $(7.72,5.53$, and 6.55$) \%$ respectively concerning the specimens (SS1, SS2, and SS3). 
- Improving the number of steel stiffeners largely enhance the capacity of punching shear which would be significant than of the control slab

\section{REFERENCES}

[1] H. Guan, Y.-C.J.C.J.o.C.E. Loo, Failure analysis of column slab connections with stud shear reinforcement, 30(5) (2003) 934-944.

[2] S.D. Alexander, S.H. Simmonds, Shear-moment transfer in slab-column connections, (1986).

[3] S. Lips, M. Fernández Ruiz, A.J.A.S.J. Muttoni, Experimental investigation on punching strength and deformation capacity of shear-reinforced slabs, 109(ARTICLE) (2012) 889-900.

[4] R.T. Mabrouk, A. Bakr, H.J.A.E.J. Abdalla, Effect of flexural and shear reinforcement on the punching behavior of reinforced concrete flat slabs, 56(4) (2017) 591-599.

[5] H.I. Qassem, A.N. Abbas, J.S.J.J.o.E. Al-Abasei, S. Development, Experimental study of flat plate construction with special embedded shearhead, 11(3) (2007) 95-107.

[6] H. Al-Wetaefi, Investigation on Punching Behavior of ShearReinforced/Repaired High Strength Concrete Flat Plates Subjected to Repeated Loads, (2016).

[7] G. Hassanzadeh, H.J.d. Sundqvist, Strengthening of Bridge Slabs on Columns. Nordic Concrete Research [online], 1998, 27 (2003) 12.

[8] Widianto, Rehabilitation of Reinforced Concrete Slab-column Connections for Two-way Shear, University of Texas Libraries, 2006.

[9] A. Ramos, V. Lucio, P. Regan, Repair and strengthening methods of flat slabs for punching, in: International workshop on punching shear capacity of RC flat slabs, Royal Institute of Technology, Department of Structural Engineering, Stockholm, 2000.

[10] H.K. Ammash, M.J. Kadhim, D.S.J.J.o.E. Ellk, S. Development, A New Punching Shear Equation of Normal and High Strength Reinforced Concrete Flat Slabs, 16(4) (2012) 47-65.

[11] H.K. Ammash, S.S.J.J.o.S.J.U. Kadhim, Effect of Reinforced Concrete Column Capital on Punching Shear Strength of Flat Slab, 54(5) (2019).

[12] M. Polak, E. El-Salakawy, N.J.S.P. Hammill, Shear reinforcement for concrete flat slabs, 232 (2005) 75-96. 